\title{
Profile Characteristics of Women Managers and their Association with Decision Making Pattern
}

\author{
Kavya H. Patil* and S. S. Dolli \\ Department of Agricultural Extension Education, College of Agriculture, Dharwad University \\ of Agricultural Sciences, Dharwad, Karnataka, India \\ *Corresponding author
}

\section{A B S T R A C T}

\section{Keywords}

Profile

characteristics,

Women managers, Decision making pattern, Factors related to decision making

\section{Article Info}

\section{Accepted:}

12 January 2021

Available Online:

10 February 2021
The study was conducted to study the profile characteristics of women managers and their association with decision making pattern. Eighty farm women who managed farms were identified in consultation with RSK field functionaries, thus forming sample of 80 farm women. The primary data was collected from farm women by using the schedule developed for the study. The results revealed that majority of farm women were found in middle age $(71.25 \%)$ group of 35 to 55 years,38.75 per cent of them studied up to high school and more number of respondents were married $(63.75 \%)$ and majority of women belonged to nuclear family $(77.50 \%)$, small family size $(60.00 \%)$,medium family income $(75.50 \%)$, medium farming experience $(37.50 \%)$, medium risk bearing ability $(52.50 \%)$, medium family support $(51.25 \%)$, low extension contact $(60.00 \%)$, low mass media utilization $(42.50 \%)$ and significantly large proportion of respondents were found in low organization participation(87.50\%) and only few attended training (17.50\%) given under KMF.The correlation coefficient between independent variables and decision making pattern of the farm womenrevealed that age, education, family size and emotional stability were positively and significantly related to decision making of women managers at five per cent level of significance whereas farming experience, family support, risk bearing ability, extension contact, organization participation, mass media utilization, training participation were positively significant at one per cent level.

\section{Introduction}

Decision-making and accurate performance of all activities helps in making an enterprise more viable, feasible and profitable. Before performing any operation task a person thinks over various options available to him/her and selects only those which are simple, profitable, compatible and relatively better. If a person before implementing a task also plans and decides about various activities, can produce excellent results. But in case of agriculture, due to gender bias, farmwomen, a significant contributor in various activities is being kept away from the role of decision maker.

In India, 75.00 per cent of rural women belong to small and marginal farmers category. Among these, 38.87 per cent are 
agricultural labourers, 32.93 per cent are cultivators. Literacy rate of women is 65.46 per cent and work participation of women is 22.50 per cent.(Census, 2011).In rural India, 84.00 per cent of women depend on agriculture for their livelihood. Women make up about 33.00 per cent of cultivators and 47.00 per cent of agricultural labourers.

In Karnataka the population of women is about 3 crores of which 19.30 per cent of women are agricultural labourers and 40.33 per cent of cultivators. Literacy rate of women is 68.10 per cent and work participation of women is 31.90 per cent as per Census, 2011.

It is a well-known fact that women play a significant and crucial role in agriculture development and allied field including in the main crop production, livestock production, horticulture, post-harvest operations, agrosocial forestry and fishery etc. She also performs several management and decision making roles in farming and home making practices with her male counterpart and sometimes alone. (Sreenivasulu and Punnarao, 2005). The nature and extent of women's involvement vary widely among ecological sub zones, farming system, caste, classes and socio-economic status of families etc.

In recent times the woman are playing important role in agricultural occupation as a manager, decision maker and skilled agricultural labour. Every woman is an entrepreneur as she manages, organizes and assume responsibility for maintaining her house. It has been increasingly realized that woman possess talent that can be harnessed for the productive purposes.

With so much of contribution by women in on farm and off farm activities it is unfortunate that agrarian Indian society relegated women to the exclusive role of doing worker rather than decision maker. Power authority and decision-making issues seem to test exclusively with the males and eventually women acquired a role slowly. Women's contribution to the farming sector in respect of operation and decision making has largely been ignored (Dude and Meena, 2017). Very few scientific and empirical attempts have been made to examine decision making efficiency of women managers with respect to farm and other farm supporting activities.

It is therefore, pertinent to examine the profile characteristics of women managers and their association in decision making pattern to account for their economic contribution at the farm level. Such study essential to assess the contribution of women in economy of the area so that hidden obstacles in uplifting the status of women could be identified and suitable suggestions could be given to overcome these obstacles. Keeping the above facts in mind present study was conducted in Haveri and Bellary districts of North Karnataka to study profile characteristics if women managers and their association with decision making pattern.

\section{Materials and Methods}

The study adopted Ex-post facto research design and conducted in Haveri and Bellary districts of North Karnataka during 2019-20. Two Taluks from each district were selected based on cropping diversity. From each taluk twenty farm women who were managing their farm were selected in consultation with RSK field functionaries thus making total sample size of 80, farm women. Purposive simple random based on random sampling method was used.

To know the association of profile characteristics of women managers with their decision making pattern Karl Pearson's 
product movement correlation coefficient (Simple correlation coefficient) was employed. Multiple linear regression analysis was used to find the contribution of independent variables to decision making of farm women.

\section{Results and Discussion}

The results pertaining to profile characteristics of farm women depicted in Table 1 reveals that majority $(71.25 \%)$ of women managers belonged to middle age group of 35 to 55 years followed by young age group of less than 35 years $(20.00 \%)$, while 21.66 per cent were of old age. This is due to the fact majority of farm women were married and some were widows. Some family, where men are engaged in other activities or not active, women had taken over and playing major role. In such situations obviously they reach middle age, however young women taking managerial role is welcome sign. The findings are in line with the findings of the studies reported by Patil (2016). She observed that 58.30 per cent of successful women entrepreneurs belonged to middle age, followed by young age category.

With regard to education 38.75 per cent of farm women educated up to high school, followed by primary school $(28.75 \%)$ and 22.50 per cent were illiterates. This might be because educated women have keen interest to take up managerial role. As education improves comprehension of things, increase knowledge about new cultivation practices.

Educated women could get idea of cost of cultivation in agricultural operations. It is because of the confidence and better education might have made fit to play managerial role. However 22.50 per cent of women are illiterate which is matter of concern. The results are in accordance with the finding of the study reported by Karigar
(2017). She observed that 26.25 per cent of the respondents were studied up to high school level, 20.00 per cent were educated up to middle school.

Results pertaining to marital status indicated that majority $(63.75 \%)$ of farm women were married and 36.25 per cent were widow. Women members normally marry at an age of 25 years and start a new life. As a family responsibility after marriage to support her family. As other members in the family engaged in other enterprises or occupation she might had engaged in farm management. Whereas in case of widowed farm women it may be compulsion to take up managerial role as there are no male member to look after farming operations. Similar findings are reported by Kumbar (2016).

Results in table 1 depicts that more number of respondents $(77.50 \%)$ of women managers belonged to nuclear family, followed by joint family $(22.50 \%)$.It is mainly due to desire to lead an independent life with proper accommodation, basic amenities and to provide better future to their kids. The results in line with study reported by Kumbar(2016). She reported that 51.66 per cent of the respondents belonged to nuclear families and 43.33 per cent of the respondents belonged to joint family.

Results presented in 1 showed that majority $(60.00 \%)$ of farm women belonged to small family size, followed by medium and big family size respectively. As discussed above under family type, over 80 per cent of women managers belonged to nuclear families. Therefore most of them had belonged to small size families to lead independent life. The findings are in accordance with study reported by Kumbar (2016). She revealed that majority $(90.00 \%)$ of the respondents belonged to small family size category. 
Table.1 Profile characteristics of the farm women $n=80$

\begin{tabular}{|c|c|c|c|}
\hline Variables & Freq. & \multirow{2}{*}{\multicolumn{2}{|c|}{ Percentage }} \\
\hline 1. Age & & & \\
\hline Young Age (<35years) & 16 & \multicolumn{2}{|l|}{20.00} \\
\hline Middle Age (35-55 years) & 57 & \multicolumn{2}{|l|}{71.25} \\
\hline Old Age $(>55$ years) & 07 & \multicolumn{2}{|l|}{08.75} \\
\hline \multicolumn{4}{|l|}{ 2. Education } \\
\hline Illiterate & 18 & \multicolumn{2}{|l|}{22.50} \\
\hline Primary school $\left(1^{\text {st }}\right.$ to $\left.4^{\text {th }}\right)$ & 23 & \multicolumn{2}{|l|}{28.75} \\
\hline Middle school $\left(5^{\text {th }}\right.$ to $\left.7^{\text {th }}\right)$ & 14 & \multicolumn{2}{|l|}{17.50} \\
\hline High school $\left(8^{\text {th }}\right.$ to $\left.10^{\text {th }}\right)$ & 31 & \multicolumn{2}{|l|}{38.75} \\
\hline PUC $\left(11^{\text {th }}\right.$ to $\left.12^{\text {th }}\right)$ & 03 & \multicolumn{2}{|l|}{03.75} \\
\hline Graduate and above & 02 & \multicolumn{2}{|l|}{02.50} \\
\hline \multicolumn{4}{|l|}{ 3. Marital status } \\
\hline Married & \multirow{2}{*}{\multicolumn{2}{|c|}{$\begin{array}{l}51 \\
29\end{array}$}} & 63.75 \\
\hline Widow & & & 36.25 \\
\hline \multicolumn{4}{|l|}{ 4. Family Type } \\
\hline Nuclear & \multicolumn{2}{|c|}{62} & 77.50 \\
\hline Joint & \multirow{2}{*}{\multicolumn{2}{|c|}{18}} & 22.50 \\
\hline \multicolumn{2}{|l|}{ 5. Family size } & & \\
\hline Small (upto 5) & \multicolumn{2}{|c|}{48} & 60.00 \\
\hline Medium (5-8) & \multicolumn{2}{|c|}{27} & 33.75 \\
\hline Big ( 8 above) & \multirow{2}{*}{\multicolumn{2}{|c|}{05}} & 06.25 \\
\hline \multicolumn{2}{|l|}{ 6. Landholding } & & \\
\hline Marginal farmer (up to 2.50 acres) & \multicolumn{2}{|c|}{14} & 17.50 \\
\hline Small farmer (2.51-5.00 acres) & \multicolumn{2}{|c|}{38} & 47.50 \\
\hline Semi-medium farmer (5.01-10.00 acres) & & & 26.25 \\
\hline Medium farmer (10.01-25.00 acres) & & & 06.25 \\
\hline Big farmer (> 25.00 acres) & & & 02.50 \\
\hline 7. Family occupation & & & \\
\hline Agriculture & 44 & 55.00 & \\
\hline Agriculture + Diary enterprise & 15 & 18.75 & \\
\hline Agriculture + Service & 12 & 15.00 & \\
\hline Agriculture + Dairy + Service & 09 & 11.25 & \\
\hline 8. Family income & & & \\
\hline Low income $(<60,000)$ & 14 & 17.50 & \\
\hline Medium income $(60,000-1,20,000)$ & 46 & 57.50 & \\
\hline High income $(>1,20,00)$ & 20 & 25.00 & \\
\hline Mean: 1,24,436 SD: 116740.41 & & & \\
\hline 9. Farming experience & & & \\
\hline Low $(<19.06)$ & 22 & 27.50 & \\
\hline Medium ( 19.06 -24.33) & 30 & 37.50 & \\
\hline High $(>24.33)$ & 28 & 35.00 & \\
\hline Mean: 21.7 SD: 6.20 & & & \\
\hline 10. Risk bearing ability & & & \\
\hline Low $(<11.21)$ & 14 & 17.50 & \\
\hline Medium (11.21-12.48) & 42 & 52.50 & \\
\hline High $(>12.48)$ & 24 & 30.00 & \\
\hline Mean: 11.85 SD: 1.49 & & & \\
\hline
\end{tabular}


Table.2 Family support of farm women

\begin{tabular}{|c|c|c|c|c|c|c|c|}
\hline \multirow{3}{*}{$\begin{array}{l}\text { Sl. } \\
\text { No }\end{array}$} & \multirow[t]{3}{*}{ Statement } & \multicolumn{6}{|c|}{ Extent of family support } \\
\hline & & \multicolumn{2}{|c|}{ Always } & \multicolumn{2}{|c|}{ Sometimes } & \multicolumn{2}{|c|}{ Never } \\
\hline & & Freq. & $\%$ & Freq. & $\%$ & Freq. & $\%$ \\
\hline 1 & $\begin{array}{l}\text { Good co - operation / support from } \\
\text { husband in carrying out agricultural } \\
\text { operations }\end{array}$ & 41 & 51.25 & 27 & 33.75 & 12 & 15.00 \\
\hline 2 & Assistance from other family members & 53 & 66.25 & 22 & 27.5 & 05 & 06.25 \\
\hline 3 & Moral support from family & 45 & 56.25 & 29 & 30.00 & 06 & 07.50 \\
\hline 4 & Do not object for the decision made & 34 & 42.50 & 29 & 42.50 & 03 & 03.75 \\
\hline 5 & Follow the instructions / work assigned & 63 & 78.75 & 43 & 21.25 & 00 & 00.00 \\
\hline
\end{tabular}

Table.3 Distribution of farm women according to family support $n=80$

\begin{tabular}{|c|l|c|c|}
\hline Sl. No. & \multicolumn{2}{|c|}{ Category } & \multicolumn{2}{c|}{ Farm women } \\
\cline { 3 - 4 } & & Freq. & Percentage \\
\hline $\mathbf{1}$ & Low $(<10.89)$ & 16 & 20.00 \\
\hline $\mathbf{2}$ & Medium(10.89-12.39) & 41 & 51.25 \\
\hline $\mathbf{3}$ & High $(>12.39)$ & 23 & 28.75 \\
\hline & & & \\
\hline
\end{tabular}

Table.4 Extension contact of farm women $n=80$

\begin{tabular}{|c|c|c|c|c|c|c|c|c|c|c|c|}
\hline \multirow{3}{*}{$\begin{array}{l}\text { Sl. } \\
\text { No. }\end{array}$} & \multirow{3}{*}{ Extension worker } & \multicolumn{10}{|c|}{ Extent of contact } \\
\hline & & \multicolumn{2}{|c|}{$\begin{array}{c}\text { Once in a } \\
\text { week }\end{array}$} & \multicolumn{2}{|c|}{$\begin{array}{c}\text { Once in } \\
\text { fortnight }\end{array}$} & \multicolumn{2}{|c|}{$\begin{array}{l}\text { Once in a } \\
\text { month }\end{array}$} & \multicolumn{2}{|c|}{ Occasionally } & \multicolumn{2}{|c|}{ Never } \\
\hline & & freq & $\%$ & Freq & $\%$ & Freq & $\%$ & Freq & $\%$ & Freq & $\%$ \\
\hline 1 & $\begin{array}{l}\text { Assistant Agriculture } \\
\text { Officer }\end{array}$ & 00 & 00.00 & 00 & 00.00 & 02 & 02.50 & 45 & 56.25 & 33 & 41.25 \\
\hline 2 & Agriculture Officer & 00 & 00.00 & 00 & 00.00 & 00 & 00.00 & 41 & 51.25 & 39 & 48.75 \\
\hline 3 & $\begin{array}{l}\text { Assistant Director of } \\
\text { Agriculture }\end{array}$ & 00 & 00.00 & 00 & 00.00 & 00 & 00.00 & 01 & 01.25 & 79 & 98.75 \\
\hline 4 & $\begin{array}{l}\text { Assistant Horticulture } \\
\text { Officer }\end{array}$ & 00 & 00.00 & 00 & 00.00 & 00 & 00.00 & 18 & 22.50 & 62 & 77.50 \\
\hline 5 & $\begin{array}{l}\text { Assistant Director of } \\
\text { Horticulture }\end{array}$ & 00 & 00.00 & 00 & 00.00 & 00 & 00.00 & 11 & 13.75 & 69 & 86.25 \\
\hline 6 & $\begin{array}{l}\text { Agriculture Scientists } \\
\text { (UAS/KVK) }\end{array}$ & 00 & 00.00 & 00 & 00.00 & 00 & 00.00 & 12 & 15.00 & 68 & 85.00 \\
\hline 7 & Input dealers & 00 & 00.00 & 00 & 00.00 & 00 & 00.00 & 34 & 30.00 & 46 & 57.50 \\
\hline 8 & Informal source & 64 & 80.00 & 11 & 13.75 & 05 & 06.25 & 00 & 00.00 & 00 & 00.00 \\
\hline
\end{tabular}

Table.5 Distribution of farm women according to Extension contact $n=80$

\begin{tabular}{|c|l|c|c|}
\hline \multirow{2}{*}{ SI. No. } & \multicolumn{1}{|c|}{ Category } & \multicolumn{2}{|c|}{ Farm women } \\
\cline { 3 - 4 } & & Freq. & Percentage \\
\hline $\mathbf{1}$ & Low $(<10.57)$ & 48 & 60.00 \\
\hline $\mathbf{2}$ & Medium $(10.57-12.02)$ & 24 & 30.00 \\
\hline $\mathbf{3}$ & High $(>12.02)$ & 08 & 10.00 \\
\hline Mean: 11.30 SD: 1.70 & & \\
\hline
\end{tabular}


Table.6 Mass media utilization of farm women

\begin{tabular}{|c|c|c|c|c|c|c|c|c|}
\hline \multirow{3}{*}{$\begin{array}{l}\text { Sl. } \\
\text { No. }\end{array}$} & \multirow[t]{3}{*}{ Mass media } & \multirow{3}{*}{$\begin{array}{c}\text { Programmes/ } \\
\text { Article/ Information }\end{array}$} & \multicolumn{6}{|c|}{ Frequency of utilization } \\
\hline & & & \multicolumn{2}{|c|}{ Frequently } & \multicolumn{2}{|c|}{ Often } & \multicolumn{2}{|c|}{ Never } \\
\hline & & & Freq & $\%$ & freq & $\%$ & freq & $\%$ \\
\hline 1 & TV & Agriculture programmes & 42 & 52.50 & 30 & 37.50 & 08 & 10.00 \\
\hline 2 & Newspaper & $\begin{array}{l}\text { Agriculture events, } \\
\text { Agriculturespecial articles }\end{array}$ & 12 & 15.00 & 44 & 55.50 & 24 & 30.00 \\
\hline 3 & Internet & Agriculture information & 03 & 03.75 & 06 & 07.50 & 71 & 88.75 \\
\hline 4 & Smartphone & Agriculture information & 09 & 11.75 & 17 & 21.25 & 54 & 67.50 \\
\hline
\end{tabular}

Table.7 Distribution of farm women according to Mass media utilization $n=80$

\begin{tabular}{|c|l|c|c|}
\hline Sl. No. & \multicolumn{2}{|c|}{ Category } & Farm women \\
\cline { 3 - 4 } & & Freq. & Percentage \\
\hline $\mathbf{1}$ & Low $(<7.57)$ & 34 & 42.50 \\
\hline $\mathbf{2}$ & Medium $(7.57-8.59)$ & 26 & 32.50 \\
\hline $\mathbf{3}$ & High $(>8.59)$ & 20 & 25.00 \\
\hline & \multicolumn{2}{|c|}{ Mean : 8.08 SD: 1.20 } \\
\hline
\end{tabular}

Table.8 Organization participation of farm women $n=80$

\begin{tabular}{|c|c|c|c|c|c|c|c|c|c|c|c|}
\hline \multirow{3}{*}{$\begin{array}{l}\text { Sl. } \\
\text { no. }\end{array}$} & \multirow[b]{3}{*}{ Organisation } & \multirow{2}{*}{\multicolumn{2}{|c|}{ Member }} & \multirow{2}{*}{\multicolumn{2}{|c|}{ Office bearer }} & \multicolumn{6}{|c|}{ Extent of participation } \\
\hline & & & & & & \multicolumn{2}{|c|}{ Regular } & \multicolumn{3}{|c|}{ Occasional } & \multirow{2}{*}{$\begin{array}{c}\text { Never } \\
\%\end{array}$} \\
\hline & & Freq. & $\%$ & Freq. & $\%$ & Freq. & $\%$ & Freq & $\%$ & Freq & \\
\hline 1 & Gram sabha & 05 & 06.25 & 01 & 01.25 & 00 & 00.00 & 05 & 06.25 & 75 & 93.75 \\
\hline 2 & Dairy co-operative society & 08 & 10.00 & 02 & 02.50 & 00 & 00.00 & 13 & 16.25 & 67 & 83.75 \\
\hline 3 & SH Groups & 37 & 46.25 & 17 & 21.25 & 30 & 37.50 & 38 & 47.50 & 12 & 15.00 \\
\hline
\end{tabular}

Table.9 Distribution of farm women according to organization participation $n=80$

\begin{tabular}{|c|l|c|c|}
\hline \multirow{2}{*}{ Sl. No. } & \multicolumn{1}{|c|}{ Category } & \multicolumn{2}{c|}{ Farm women } \\
\cline { 3 - 4 } & & Freq. & Percentage \\
\hline $\mathbf{1}$ & Low $(<1.72)$ & 70 & 87.50 \\
\hline $\mathbf{2}$ & Medium(1.72-2.59) & 08 & 10.00 \\
\hline $\mathbf{3}$ & High $(>2.59) \quad 02$ & 02.50 \\
\hline \multicolumn{2}{|r|}{ Mean: 2.16 SD: 1.02 } \\
\hline
\end{tabular}

Table.10 Training participation of farm women $n=80$

\begin{tabular}{|c|l|c|c|}
\hline \multirow{2}{*}{ Sl.no } & \multicolumn{1}{|c|}{ Institution } & \multicolumn{2}{c|}{ Farm women } \\
\cline { 3 - 4 } & & Freq. & Percentage \\
\hline $\mathbf{1}$ & KVKs & 06 & 07.50 \\
\hline $\mathbf{2}$ & Others $(\mathrm{KMF})$ & 14 & 17.50 \\
\hline
\end{tabular}


Table.11 Emotional stability of farm women $n=80$

\begin{tabular}{|c|c|c|c|c|c|c|c|c|c|c|c|}
\hline \multirow{3}{*}{$\begin{array}{l}\text { Sl. } \\
\text { no }\end{array}$} & \multirow[t]{3}{*}{ Statement } & \multicolumn{10}{|c|}{ Extent of Emotional stability } \\
\hline & & \multicolumn{2}{|c|}{$\begin{array}{c}\text { Agree } \\
\text { strongly }\end{array}$} & \multicolumn{2}{|c|}{ Agree a little } & \multicolumn{2}{|c|}{$\begin{array}{l}\text { Neither agree } \\
\text { nor disagree }\end{array}$} & \multicolumn{2}{|c|}{$\begin{array}{c}\text { Disagree a } \\
\text { little }\end{array}$} & \multicolumn{2}{|c|}{$\begin{array}{l}\text { Disagree } \\
\text { strongly }\end{array}$} \\
\hline & & Freq & $\%$ & Freq. & $\%$ & Freq. & $\%$ & Freq. & $\%$ & Freq & $\%$ \\
\hline 1 & I see myself as someone who is depressed & 02 & 02.50 & 06 & 07.50 & 05 & 06.25 & 28 & 35.00 & 39 & 48.75 \\
\hline 2 & $\begin{array}{l}\text { I see myself as someone who is relaxed, } \\
\text { handles stress well }\end{array}$ & 19 & 23.75 & 33 & 41.25 & 18 & 22.50 & 08 & 10.00 & 02 & 02.50 \\
\hline 3 & I see myself as someone who can be tense & 01 & 01.25 & 09 & 11.25 & 02 & 02.50 & 21 & 26.25 & 47 & 58.75 \\
\hline 4 & I see myself as someone who worries a lot & 03 & 03.75 & 16 & 20.00 & 13 & 16.25 & 28 & 35.00 & 20 & 25.00 \\
\hline 5 & $\begin{array}{l}\text { I see myself as someone who is emotionally } \\
\text { stable, not easily upset }\end{array}$ & 07 & 08.75 & 32 & 40.00 & 09 & 11.25 & 27 & 33.75 & 15 & 18.75 \\
\hline 6 & I see myself as someone who can be moody & 03 & 3.75 & 11 & 13.75 & 19 & 23.75 & 25 & 31.25 & 22 & 27.50 \\
\hline 7 & $\begin{array}{l}\text { I see myself as someone who remains calm in } \\
\text { tense situations }\end{array}$ & 06 & 7.50 & 32 & 40.00 & 29 & 36.25 & 08 & 10.00 & 05 & 06.25 \\
\hline 8 & $\begin{array}{l}\text { I see myself as someone who gets nervous } \\
\text { easily }\end{array}$ & 02 & 02.50 & 03 & 03.75 & 07 & 08.75 & 28 & 35.00 & 42 & 52.50 \\
\hline
\end{tabular}

Table.12 Distribution of farm women based on emotional stability $n=80$

\begin{tabular}{|c|l|c|c|}
\hline Sl. No. & \multicolumn{2}{|c|}{ Category } & \multicolumn{2}{c|}{ Farm women } \\
\cline { 3 - 4 } & & Freq. & Percentage \\
\hline $\mathbf{1}$ & Low $(<17.97)$ & 12 & 15.00 \\
\hline $\mathbf{2}$ & Medium $(17.97-21.20)$ & 46 & 57.50 \\
\hline $\mathbf{3}$ & High $(<21.20)$ & 22 & 27.50 \\
\hline & & & Mean: 19.58 SD: 3.80 \\
\hline
\end{tabular}

Table.13 Association between independent variables and decision making of farm women $n=80$

\begin{tabular}{l|c|l|c|}
\hline Sl. No. & \multicolumn{1}{c|}{ Independent Variables } & 'r' Value \\
\hline $\mathbf{1}$ & Age & $0.210^{*}$ \\
\hline $\mathbf{2}$ & Education & $0.224^{*}$ \\
\hline $\mathbf{3}$ & Marital status & $0.029^{\mathrm{NS}}$ \\
\hline $\mathbf{4}$ & Family type & $0.148^{\mathrm{NS}}$ \\
\hline $\mathbf{5}$ & Family size & $0.194^{*}$ \\
\hline $\mathbf{6}$ & Landholding & $0.136^{\mathrm{NS}}$ \\
\hline $\mathbf{7}$ & Family occupation & $0.142^{\mathrm{NS}}$ \\
\hline $\mathbf{8}$ & Family income & $0.163^{\mathrm{NS}}$ \\
\hline $\mathbf{9}$ & Farming experience & $0.342^{\text {** }}$ \\
\hline $\mathbf{1 0}$ & Family support & $0.287^{* *}$ \\
\hline $\mathbf{1 1}$ & Risk bearing ability & $0.296^{* *}$ \\
\hline $\mathbf{1 2}$ & Extension contact & $0.336^{* *}$ \\
\hline $\mathbf{1 3}$ & Mass media utilization & $0.251^{* *}$ \\
\hline $\mathbf{1 4}$ & Organization participation & $0.321^{* *}$ \\
\hline
\end{tabular}


The study also revealed that nearly fifty per cent $(47.50 \%)$ of farm women possessed small size land holding, followed by semi medium $(26.25 \%)$ size of land holding and marginal $(17.50 \%)$ respectively. Inheritance of land from their ancestors and fragmentation of land holding among the family members made them to possess small and semi- medium size of land holding. This may be reason why most of the farm women belonged to small and semi medium size of land holding. Similar findings are also reported by Hagone and Basunathe (2015).

The results related to family occupation indicated that over fifty per cent $(55.00 \%)$ of the farm women family engaged in agriculture alone followed by 18.75 per cent of farm women family engaged in agriculture + dairy enterprise, 15 per cent in agriculture + service and about 11.25 per cent of farm women family engaged in agriculture + dairy + service respectively. As majority belongs to small and medium land holding category, agriculture was main occupation. However few women managers's family carried out dairy enterprise and other service along with agriculture in order to support their family income. The findings are on par with study reported by Karigar (2017). She reported that 76.25 per cent of the entrepreneurs were solely dependent on agriculture and that was their main occupation. About 16.25 per cent of them were engaged in dairy, followed by service personnel (11.25\%), vegetable cultivation $(10.00 \%)$ and waged labour $(8.75$ $\%)$.

The results presented in table 1 showed that majority $(57.50 \%)$ of farm women belonged to medium income category of Rs. 60,000$1,20,000$ and followed by high $(25.00 \%)$, income category of Rs. $>1,20,000$. This might be due to small sized and uneconomical land holding, farm women might have less income, and also majority of women managers followed rainfed agriculture resulting in medium to low income. The results are in accordance with Kumbar (2016). She observed that 36.67 per cent famers had medium family income of Rs 11,001-22,000 and only 15 per cent of the farmers had family income above Rs 33,000.

The data in table 1 indicated that 37.50 per cent of the farm women had medium farming experience, followed by high and low farming experience respectively. Farming experience relies primarily on age of the farm women. Since agriculture is main occupation of farm women family in the study area. They might have started to practice agriculture as their main occupation after their marriage. The findings are in line with findings reported by Kumbar (2016) who revealed that 48.33 per cent of the respondents belonged to medium farming experience category followed by, low and high farming experience.

Results in table 1 pertaining to risk bearing ability indicated that slightly more than half per cent $(52.50 \%)$ of women managers belonged to medium risk bearing category, followed by high and low categories of risk bearing ability. This trend might be due to reason that most of the farm women had medium to high farming experience, medium emotional stability and education which might have contributed to take risk. Family support had also helped to take risk. Similar findings are noticed by Sreenivasulu and Rao (2005) and Balambeed (2018) who had reported that majority of the respondents belonged to medium to high risk bearing ability.

Results in table 2 depicts that majority of farm women 'always' had family support regarding 'Follow the instructions/work assigned'(78.75\%), 'Assistance from other family members'(66.25\%), 'Moral support from family'(56.25\%), 'Good co-operation / support from husband in carrying out 
agricultural operations'(51.25 \%) respectively. Farm women find difficult to take decisions without active support of family and friends in organizing and coordinating the activities for timely completion of work. Those women who make their mind to take managerial role need moral support from husband, in laws, as well as children. Co-operation and support from the family and friends also increase their confidence level. Guidance given by family members had helped to increase her managerial efficiency and also to take independent decisions.

Family support is an essential factor to exhibit managerial role by farm women. From table 3 indicated that majority of farm women had medium $(51.25 \%)$ family support followed by high $(28.75 \%)$ family support. Similar findings are reported by Sunandha (2015) She observed that most of the women entrepreneurs $(63.50 \%)$ got good support from their husbands for running the business, followed by 15.50 per cent of the entrepreneurs revealed they received help from parents. From table 3 it is observed that slightly more than half $(51.25 \%)$ of the women managers had medium family support followed by high $(28.75 \%)$ family support. Similar findings are reported by Sunandha (2015).

From Table 4 it is noticed that majority $(60.00$ $\%$ ) of farm women belonged to low category of extension contact, followed by medium category of extension contact. Might be due to majority of extension agents were men whom rural women feel hesitated to contact because of shyness and other social barriers. Presence of meagre per cent of female extension workers with whom farm women can directly meet may be a reason for above findings. From table 5 it can be observed that majotity of respondents had low extension contact $(60.00 \%)$ followed by medium and high extension contact. The findings are in conformity with studies reported by Basanayak and Manjunath (2013). They observed that 40per cent of the awardee farmers had low level of extension contact, 30.38 per cent had medium level followed by high level $(29.16 \%)$ of extension contact.

Results in table 6 indicated that slightly more than half per cent $(52.50 \%)$ of farm women were found to watch agricultural programmes on TV 'frequently' followed by watching 'oftenly'. This is due to fact that increasing popularity and monopolization of television dominated its use over the other mass media because of its strong audio visual impact on viewers. They watch agricultural programmes in order to become aware of specific practices with regard to crop cultivation which help them improve managerial role on these specific aspects of cultivation and postharvest operations of the crop production. In case of Newspaper 55.50 per cent of farm women red agricultural articles 'oftenly', followed by 15 per cent red 'frequently', 30 per cent 'never' red newspaper Further in case of use of internet and smart phone majority $(88.75 \%$ and $67.50 \%)$ of farm women 'never' used internet and smart phones for agricultural information. This might be due to lack of facility and time as women have to carry the operations of farm as well as home and also majority of them are found to have medium family income which made them unable to own smart phones and internet connection, lack of technical knowledge deprived them using mobile. Further table 7 revealed that 42.50 per cent women managers belonged to low level of mass media utilization followed by medium (32.50\%) level of mass media utilization. Similar findings are reported by Sowjanya (2014 ). She observed that 59.16 per cent of the dairy farm women belonged to medium category, while 34.16 per cent in low mass media utilization category. 
A careful observation of data in table 8 indicated that majority $(93.75 \%$ and $83.75 \%)$ of farm women were 'never' participated in gram sabha and dairy cooperative that may be because of lack knowledge, discouragement for exposure and shyness and also lack of time due to family ties and farming activities to participate in those organizations as they need to regularly attend meetings. In case of SHG activities, it is revealed that nearly fifty per cent $(47.50 \%)$ of farm women were occasionally participated in SHG activities, while 30per cent regularly participated and 15 per cent of them 'never' participated in SHG activities. From table 9 it could be observed that large majority $(87.50 \%)$ belonged to low organization participation category, followed by medium $(10.00 \%)$ and low $(02.50 \%)$ levels of organization participation. This might be due to reason that SHG involves only women and they feel comfortable to participate with them and moreover farm women can avail loan from SHGs to carry out farm operations. The findings are on par with the study reported by Rathod et al (2011). Who reported that majority $(71.66 \%)$ of rural women had low level of organization participation while 20.84 per cent had medium level of organization participation.

The data in table 10 indicated training participation only 17.50 per cent of farm women had taken training from KMF, followed by KVK $(07.50 \%)$. This might be due to fact that women burdened with dual roles (i.e family and farming). They need to take care of their families so, they cannot stay away from their home. Lack of support from the family, lack of awareness about training programmes. Apart from this inconvenience of time and work might be reasons for above findings. The findings are in tune with study reported by Soumya (2009). She noticed that almost three fourth $(74.17 \%)$ of rural women had not undergone any training progrmmes and only one fourth (25.83\%) received training about agriculture and allied activities.

Data in Table 12 indicated that more than fifty per cent $(57.50 \%)$ of farm women had belonged to medium emotional category, followed by high $(27.50 \%)$ and low $(15.00$ $\%)$ levels of emotional stability. Apart from family responsibility, their education and age had helped them to be emotional stable and balanced in different situations. It is circumstances that make farm women focus, might had to develop emotional stability. She need to be more independent and face situations.

\section{Association of independent variables with decision making pattern of women managers}

The results in table 13 indicated that correlation coefficient between independent variables and decision making women managers. The age, education, family size and emotional stability were positively and significantly related with decision making pattern of farm women at 5 per cent level of significance whereas farming experience, family support, risk bearing ability, extension contact, mass media utilization, organization participation, training participation was positively significant at one per cent level. Marital status, Family type, landholding and family income were not significantly correlated with decision making pattern of women managers. Similar findings are reported by Dude and Meena (2017). They reported that age, education, size of family, size of land holding, social participation, extension participation, information seeking behaviour, cosmopolitness, economic motivation, exposure to training and management orientation factors had significantly influenced the participation and decision making pattern of farm women. 


\section{References}

Agriculture census report- 2010-11

Balambeed, S., 2017, Study on Profilistic study of young awardee farm women (YuvaShreshtaKrishiMahile) of university of agricultural sciences Dharwad.M.H.Sc. Thesis, Uni. Agric. Sci., Dharwad, Karnataka (India).

Basanayak, R., T. and Manjunath, L., 2013, Study on profile of awardee farmers in North Karnataka.Agric. Update., 8(1\&2):201-206.

Dudi, A. and Meena, M, L., 2017, Participation and decision making pattern of farm women in agriculture. AJHS, 1(12), pp-109-113.

Hagone, V. and Basunathe, V.K., 2015, Decision making pattern tribal women in Melghat region of Aaravathidistrct. Indian Res. J. Exn.Edu., 15(4): 25-26.

Karigar, G., 2017, Rural women entrepreneurship in allied agricultural activities.M.Sc. (Agri.) Thesis, Univ. Agric. Sci.Dharwad, Karnataka.

Kumbar, J. K., 2016, Decision making and sociometry models in farming. M.Sc. (Agri.) Thesis, Univ.Agric. Sci., Dharwad, Karnataka (India)

Patil, L. M., 2016, An analysis of factors determining the establishment and growth of entrepreneurship by women. M.Sc. (Agri.) Thesis, Univ. Agric. Sci., Dharwad, Karnataka (India).

Rathod, P, K., Nikam, T, R., Landge, S., Vajreshwari, S. and Hatey, A., 2011, Participation of rural women in dairy farming in Karnataka.Indian Res. J. Ext. $E d u ., 11$ (2):31.

Reshma, Bheemappa, A., Natikar, K. V., Biradar N., Mundinamani, S, M. and Havaldar,Y.N., 2014, Entrepreneurial characteristics and decision making behaviour of farm women in livestock production activities. Karnataka $J$. Agric. Sci.,27 (2): (173-176)

Soumya, T, M., 2009, A study on entrepreneurial behaviour of rural women in Mandya district of Karnataka.M. Sc. (Agri.) Thesis, Univ. Agric. Sci. Dharwad, Karnataka (India).

Sowjanya, S., 2014, Management efficiency of dairy farm women, M.Sc. (Agri.) Thesis, Univ. Agric. Sci., Dharwad, Karnataka (India).

Sreenivasalu, M. and Rao, P. P., 2005, Managerial Role of Farm Women Karnataka.J. Agric. Sci., 18 (4): 10261030.

\section{How to cite this article:}

Kavya H. Patil and Dolli, S. S. 2021. Profile Characteristics of Women Managers and their Association with Decision Making Pattern. Int.J.Curr.Microbiol.App.Sci. 10(02): 192-202. doi: https://doi.org/10.20546/ijcmas.2021.1002.024 